\title{
URBAN TOURISM COMPETITIVENESS OF SELECTED EUROPEAN CITIES
}

\author{
Alžbeta Királ'ová ${ }^{53}$ \\ Iveta Hamarneh $^{54}$
}

https://doi.org/10.31410/itema.2018.125

\begin{abstract}
Tourism is an integral part of the global economy, and it is expanding rapidly. This growth is accompanied by challenges, among which overtourism is one of the most discussed. Tourism is attracted to urban areas mostly as a result of the built cultural heritage, urban amenities, lifestyle, cultural traditions, and cultural events. An increasing number of visitors often led to inconvenience for residents and can affect the value of the visited site. Sustainable development is from this aspect a way how to manage tourism development in the destinations so that they remain competitive.

Prague and Budapest are both Capital cities and are one of the most visited urban destinations in their respective countries.

Indicators as Tourist intensity ratio, Tourist density ratio, Tourist penetration ratio, and Defert's tourism function index, Defert-Baretje's index, Charvat's index, and Schneider's index were calculated based on the data from 2017 to detect the current state of the intensity of visitors flow in the selected destinations.

Based on the results obtained in this study, it can be stated that urban tourism in Prague and Budapest will be challenged in its competitiveness if the number of arrivals with no attention to the quality of visits will continue to prioritize.
\end{abstract}

Keywords: Urban Tourism, Competitiveness, Overtourism, Sustainable Development, Prague, Budapest

\section{INTRODUCTION}

$\mathrm{U}$ rban destinations are recognized as the dominant economic engine of the global economy with the concentration of economic and social capital. They compete for investment, new technologies, financial support from different sources, as well as for incomes, which can be earned from visitors.

Tourism is to be considered a significantly important part of urban development, as it combines a competitive supply of tourism services, which corresponds to the expectations of visitors, and a positive impact on the development of regions and cities, as well as the general prosperity of their residents [1]. The competitiveness of urban tourist destinations becomes increasingly relevant to the countries that intend to control a large share of the rapidly growing tourism market.

Tourism has a positive impact on economic growth and employment in urban destinations; it helps to raise local awareness of the value of natural and cultural sites by supporting local handicrafts, cuisine, traditions or by offering alternative economic activities. Tourism is an

\footnotetext{
${ }^{53}$ University College of Business in Prague, Spálená 14, 11000 Prague, Czech Republic

${ }^{54}$ University College of Business in Prague, Spálená 14, 11000 Prague, Czech Republic
} 
essential aspect of the life of people in destinations and a means of achieving community development [2]. However, if unplanned or not adequately managed, tourism can be social, culturally and economically disruptive, and have a devastating effect on environments and local communities; it can disrupt the original lifestyle of the residents and can cause environmental deterioration, traffic congestion, and raise the living costs.

Urban tourism is one of the leading factors of economic increase in European cities [3]. The European Cities Marketing [4] reported that European cities continued their growth with a 6,5\% increase in 2017 in total overnights compared to 2016. Domestic overnights $(4,8 \%)$ grew more than international ones $(7,5 \%)$. The average number of beds was 23006 per city.

Tourism competitiveness for an urban destination is about its ability to optimize its attractiveness for residents and non-residents, to deliver quality, innovative and attractive tourism services to visitors as well as to gain market shares on the domestic and global marketplaces, while ensuring efficient and sustainable use of available resources supporting tourism [5].

In many urban destinations visitor numbers have been rising steadily for decades, and currently, there are around two billion tourist arrivals per year. Governments, tourist boards, and destination management organizations have for long focused on quantity of arrivals with no attention to the quality of visits. Overtourism reduces the quality of life for residents, creates a negative experience for visitors and can result in a decrease in the competitiveness of the destination.

\section{COMPETITIVENESS OF URBAN TOURISM}

Urban tourism ,takes place in an urban space with its inherent attributes characterized by nonagricultural based economy such as administration, manufacturing, trade, and services and by being nodal points of transport. Urban/city destinations offer a broad and heterogeneous range of cultural, architectural, technological, social and natural experiences and products for leisure and business" [6].

According to the United Nations, in 2016, fifty-four percent of the world's population lived in urban areas and, by 2050, this share is expected to reach sixty-eight percent. Cities account for $45 \%$ of global international travel with over half a billion trips taken to urban areas annually. Cities often serve as key gateways for travel to other destinations in the particular country or abroad. The World Travel \& Tourism Council's (WTTC) annual City Travel \& Tourism Impact Report 2018 states that travel to cities has grown faster than total international travel demand in the past decade. According to the Oxford Economics' Global City Travel (GCT), as cited in WTTC report, international trips to 300 of the largest city travel destinations accounts for over half a billion trips per year, which amount to $45 \%$ of global international travel. [7]

Along with other vital pillars, tourism constitutes a central component in the economy, social life and the geography of many cities in the world and is thus a key element in urban development policies. Without a doubt, urban tourism can generate income and employment in the urban area.

In the tourism literature there is a continual interest in the competitiveness of the destinations, e. g. in work in Buhalis [8], Crouch [9], or Dwyer and Kim [10]. Competition in tourism is very often identified with the price of products and is restricted to the micro-level [11]. 
However, many other variables also determine the competitiveness of a tourist destination [11], [9], [10].

OECD defines destination competitiveness as "the ability of the place to optimize its attractiveness for residents and non-residents, to deliver quality, innovative, and attractive (e.g. providing good value for money) tourism services to consumers and to gain market shares on the domestic and global marketplaces, while ensuring that the available resources supporting tourism are used efficiently and sustainably" [5].

Some authors e. g., Bovaird [12], Cheshire and Gordon [13], Lever [14], Meijer [15], Sinkienè [16], Kresl and Singh [17] analyzing urban competitiveness emphasized that urban areas are competing to attract investment, population, labor, funds, tourists. Thus, the city's competitiveness includes the conditions that make it attractive not only to entrepreneurs wishing to invest, incoming tourists or residents but also for existing residents and businesses.

Urban tourism competitiveness reflects the ability of the city to highlight its attractiveness for visitors, provide goods and services for them better than other cities do. The cities will be able to do so if the development of tourism will be managed sustainably.

The WTTC and McKinsey\&Company report coping with Success Managing Overcrowding in Tourism Destinations [18] stated that challenges accompany the positive growth of tourism as overtourism. The report highlights that overtourism is a complex issue and as the stakeholders' interests and objectives are diverse the solution is not always working for all of them.

\section{METHODOLOGY}

The analysis and data presented in this paper are based on primary and secondary research. In order to determine the current state as well as the dynamics and direction of the changes in the competitiveness of Prague and Budapest, indicators as Tourist Intensity Ratio (TIR), Tourist Density Ratio (TDR), Tourist Penetration Ratio (TPR) and Defert's Tourist Function /DTF) Index, Defert-Baretje's Index, Charvat's Index, and Schneider's Index were calculated [19], [20], [21], [22].

Table 1: Tourism indicators

\begin{tabular}{|c|c|}
\hline Indicator & Description \\
\hline Tourist Intensity Ratio (TIR) & The percentage of tourists to the residents \\
\hline Tourist Density Ratio (TDR) & Percentage of tourists to land area $=$ tourist arrivals $/ \mathrm{km}^{2}$ \\
\hline Tourism Penetration Ratio (TPR) & $\begin{array}{l}\text { Number of tourists multiplied by average length of stay and } \\
\text { divided by number of population multiplied by } 365 \text { multiplied } \\
\text { by } 1000\end{array}$ \\
\hline Defert's tourist function index (DTF) & $\begin{array}{l}\text { The number of total beds available in the selected area divided } \\
\text { by number of residents multiplied by } 100\end{array}$ \\
\hline Defert-Baretje's index & $\begin{array}{l}\text { Number of beds multiplied by } 100 \text { divided by the number of } \\
\text { residents } \\
\text { Multiplied by } 1 \text { divided by the surface of researched area, } \\
\text { represented in } \mathrm{km}^{2}\end{array}$ \\
\hline Charvat's index & $\begin{array}{l}\text { The intensity of tourism development; the number of overnights } \\
\text { divided by the number of residents multiplied by } 100 \text {. }\end{array}$ \\
\hline Schneider's index & $\begin{array}{l}\text { The intensity of tourist saturation; the number of tourists } \\
\text { divided by the number of residents multiplied by } 100\end{array}$ \\
\hline
\end{tabular}

Determining the tourism potential, literature review, content analysis of documents and Asset Mapping [23], [24] was conducted. 
For Asset Mapping the 2GIS application, a detailed and current information system Prague with a city map and introducingbudapest.com for Budapest, was used.

Data for the calculation of the tourism indicators were obtained from CzechTourism [25], Czech Statistical Office [26], Ministry of Regional Development of the Czech Republic [27], Prague City Tourism [28], [29], Hungarian Central Statistical Office [30], and TourMis [31]. According to the objective of the paper the research question was defined as follows: Can urban tourism be perceived as competitive and sustainable in Prague and Budapest cities?

\section{RESULTS AND DISCUSSION}

The area of Prague is for the performance of the state administration divided into 22 administrative districts, and 57 autonomous municipal districts with elected bodies (Table 2) [28], [26].

The Quality of Life Index of Numbeo ranked Prague 27th very high with 158,43 points as of November 2018. Quality of Life Index is an estimation of overall quality of life by using an empirical formula which takes into account purchasing power index, pollution index, house price to income ratio, cost of living index, safety index, health care index, traffic commute time index and climate index [32].

Prague's historical center belongs since 1992 to the UNESCO World Heritage Sites. There are 1.330 protected objects in this area (including 28 national cultural monuments), 1.322 protected buildings, a large number of small architectural objects, technical monuments, and historic gardens and parks.

The most visited monument in 2017 was the Prague Castle, followed by Petrrín Funicular, the Zoological Garden, the AquaPalace and the Petřín Lookout Tower [25].

Table 2: Basic characteristics of Prague and Budapest

\begin{tabular}{l|ll}
\hline Indicator & Prague & Budapest \\
\hline Size of the area & $496 \mathrm{~km}^{2}$ & $525,14 \mathrm{~km}^{2}$ \\
Number of inhabitants & 1,273 million & 1,750 million \\
Population density & 2,581 & 3,332 \\
& inhabitants $/ \mathrm{km}^{2}$ & inhabitants $/ \mathrm{km}^{2}$ \\
Administrative districts & 22 & 23 \\
\hline
\end{tabular}

In 2017, seven million six hundred fifty thousand tourists arrived in Prague; by 7.4 percent more than a year ago [28]. The number of overnights in Prague increased in 2017 of $7,5 \%$ to compare to 2016 and reached 18. 055.838, while the average length of stay 2,4 nights remains unchanged. Prague, which ranks 18th globally, is the only emerging European city to feature in the top 50 cities by Euromonitor International [33].

Budapest is the Capital City of Hungary, and for the performance of the state administration, it is divided into 23 administrative districts (Table 2). The Quality of Life Index of Numbeo [32] ranked Budapest 158th high with 125.20 points.

Hundred and twenty hot springs supplying water of 35-76 degrees centigrade gave rise to a culture of spas in the Roman Age and made Budapest one of the most popular spa cities of Europe with more than 30 spa facilities. The city, including the banks of the Danube, the Buda Castle Quarter, and Andrássy Avenue, was listed a UNESCO World Heritage site in 1987. The 
most visited monuments in Budapest are the Parliament, the Fishermenś Bastion, St. Stephan Basilica, The St. Matthias Church and the Zoological Garden.

According to Euromonitor International, the number of visitors in Budapest reached 3,5 million in 2017 (an increase of $9.0 \%$ to 2016), while the number of overnights was over 10 million (11.1\% growth to compare to 2016) making it one of the leading European performers regarding growth. The average length of stay was 2,5 days [33].

Annual tourism density in the cities included in the ECM report [4] was determined to be 8.33 overnights per citizen. Prague is the seventh place on the list of the ECM while to the first five places belong London, Paris, Berlin, Rome, and Madrid; Budapest is placed on the 53rd position.

The number of tourists coming to Prague and Budapest has been growing in the past decades, which is due to reasonably priced accommodation facilities (e. g., Airbnb), low-cost flights, and tourist attractions. Active Airbnb rentals in 2017 were estimated as of 4025 in Budapest; however, up to $90 \%$ of the owners of these properties offered for rent do not register the accommodation, so this information is not available on the Hungarian Central Statistical Office $[30]$.

The WTTC annual City Travel \& Tourism Impact Report 2018 ranks Budapest for fourth $(95,7 \%)$ and Prague for ninth $(54,8 \%)$ position among 72 cities, according to the share of country tourism.

International tourists spent during their stay in Hungary $88,7 \%$ (6,2 bn US\$) of their total spending in Budapest; in the Czech Republic spent international visitors 87.4\% (5,6 bn US\$) of their total spending in Prague. The average ten years direct GDP growth in Budapest is $6.2 \%$ while in Prague 5.6\% [7].

Regarding Travel \& Tourism (TT) direct employment Budapest's share on total TT direct employment in Hungary is $86.1 \%$; Prague's share on country's TT direct employment is $41.1 \%$. Budapest belongs to ten fastest growing cities in direct TT employment growth with 3.9\% p.a. while Prague's TT employment decrease by $2.0 \%$ p.a. on average in ten years [7].

For detection of the current state of the intensity of visitors flow in Prague and Budapest, different tourism indicators were calculated (Table 5) [26], [27], [28], [29], [30], [31].

Table 5: Indicators for Prague and Budapest (2017)

\begin{tabular}{l|ll}
\hline Indicator & Prague & Budapest \\
\hline Tourist Intensity Ratio (TIR) & 601 & 228 \\
Tourist Density Ratio (TDR) & $15,429 / \mathrm{km}^{2}$ & $8,188 / \mathrm{km}^{2}$ \\
Tourism Penetration Ratio (TPR) & 39,5 & 14,37 \\
Defert's tourist function index (DTF) & 7,22 & 3,2 \\
Defert-Baretje's index & 2,79 & 6,1 \\
Charvat's index & $1,418,37$ & 530 \\
Schneider's index & 600,94 & 228 \\
\hline
\end{tabular}

Based on the analysis given, the following results can be stated. The Tourism Intensity measures provide an estimate of tourism potential, and in the context of the sustainable development of tourism, it can also be seen as an indicator of the possible tourism pressure. The ratio shows that Prague City (601) has a higher volume of tourism than Budapest (218) per 1000 of 
residents. The Tourist Density Ratio indicates that Prague welcomes two times more tourists per day per $1 \mathrm{~km}^{2}$ than Budapest.

Budapest is larger regarding population and has a bigger central area where tourists can congregate. Prague's most visited city center is comprised of narrow streets in a small area of $2 \mathrm{~km}^{2}$. In his research Kádár [35] explored the relationship between urban pedestrian crossnetwork and sustainable tourism. He states that the more complex cross-network offers greater freedom of routing between two sights to locals and tourists. They can have better use of urban spaces and do not concentrate in certain parts of the city.

In Prague, the most important sights of tourists take one another, along a clear path. The branching paths are connected to only a few places. The town resembles a museum where the tourists move from room to room to discover new objects. In Budapest, the main sights are concentrated on the Buda side, while on the Pest side the use of space by locals and visitors is much more balanced.

Prague's Tourist Penetration Ratio indicates more than two times higher number of tourists per day per 1000 residents than Budapest in the long term; the number of residents in Budapest is higher in Prague.

The Defert's tourist function index for Prague City (7.22) indicates low tourist intensity and that the tourism function of the City is submerged in other urban function. The Defert's index value for Budapest $(3,2)$ indicates no tourist intensity. It must be added that this result will be different if only the Prague City Center and the Budapest City Center and the 7th district area would be measured.

The Defert-Baretje's index indicates whether tourism development encourages intensive construction of accommodation facilities. The value of the index for Prague is less than 4 and indicates that tourist activity in the destination is low. Tourists' activity in Prague already reached its peak, and currently, this activity is slowed down. The number of accommodation facilities dropped from 845 in 2012 to 787 in 2017, which means a decrease of seven percent [28]. Prague, according to current tourism statistics, was the only region in the Czech Republic in 2017, where the number of overnight stays in commercial accommodation facilities decreased by 1.1 percent; the reason can be seen in the full offer of e. g., Airbnb facilities [36].

The value of the index for Budapest is 6,1 which is in accordance with the objective of the development strategy which expects to add 2,600 hotel rooms to the current market till the end of 2018.

The intensity of tourism development (the Charvat's index values) is nearly triple for Prague as for Budapest. The number of overnights is a valuable indicator of economic development as incomes achieved in this way remain to the local population, with the possibility of investing in further development.

Schneider's index indicates the tourist turnover intensity of specific destination through the number of tourist arrivals. It reflects the intensity of tourist saturation, which refers to the balance between the tourist and general spatial planning for the needs of the local community. The value of the index in Prague shows nearly a triple tourism saturation comparing to Budapest. 


\section{CONCLUSION}

Tourism is an integral part of urban development, as it combines competitive tourism services, impacts the development of cities, and generates income and jobs to their residents.

The analysis carried out in this study demonstrates disproportions in the range of the indicators. The low value of the Defert-Baretje's index and Charvat's and Schneider's indexes for Budapest indicate possibilities for further tourism development.

Based on the results obtained in this study, the research question stated for this study can be answered for Prague that urban tourism in this city is reaching its peak and the borders of sustainability. The impact of the sharing economy on Prague's short-term accommodation market is significant, but hard to track.

The indexes calculated for urban tourism in Budapest indicate that tourism can be further developed. The problem of the further development of urban tourism in this city can be seen in a huge number of tourists in accommodation facilities, often in residential areas that are not included in statistics. Overtourism reduces the quality of life for residents and creates a negative experience for visitors. The city realized its real impact first in 2017 when there were marches in the streets and graffiti saying "Tourists go home."

Governments, tourist boards, and destination management organizations have for long focused on quantity of arrivals with no attention to the quality of visits. If this attitude does not change, both cities will be challenged in competitiveness.

The opportunities for future research can be seen in widening the research and calculating the indicators for time series data.

\section{Acknowledgment}

The Scientific Paper was elaborated within the framework of the research project "Evaluation of City Tourism Competitiveness: A Comparative Study of Selected Czech Cities" GA/6/2018.

\section{REFERENCES}

[1] ECVTU (2008) Prieiga per internetą. [online]. [quoted to 01. 06. 2018]. Available at: http://ec.europa.eu/enterprise/services/tourism/index_en.htm.

[2] Sharpley, R. - Telfer, D. J. (2002) Tourism and Development: Concepts and Issues. Channel View Publications: Clevedon.

[3] Delitheou, V. - Vinieratou, M. - Touri, M. (2010) The contribution of public and private investments to the growth of conference tourism in Greece. In Management Research and Practice, 2(2), pp. 165-178.

[4] ECM (2018) The European Cities Marketing Benchmarking Report. $14^{\text {th }}$ Official Eddition 2017-2018. Dijon: European Cities Marketing.

[5] Dupeyras, A. - Maccallum, N. (2013) Indicators for Measuring Competitiveness in Tourism: A Guidance Document. [online]. OECD Tourism Papers, 2013/02, OECD Publishing.

[6] World Tourism Organization and World Tourism Cities Federation (2018) UNWTO/WTCF City Tourism Performance Research, UNWTO, Madrid, DOI: https://doi.org/10.18111/9789284419616. 
[7] World Travel and Tourism Council. City Travel \& Tourism Impact 2018 Highlights. [online]. [quoted to 01. 06. 2018]. Available at: https://www.wttc.org//media/files/reports/economic-impact-research/cities-2018/city-travel-and-tourism2018-highlights.pdf

[8] Buhalis, D. (2000) Marketing the competitive destination of the future. In Tourism Management, 21, pp. 97-116.

[9] Crouch, G. (2011) Destination competitiveness: An analysis of determinant attributes. In Journal of Travel Research, 50(1), pp. 27-45.

[10] Dwyer, L. - Kim, C. (2003) Destination competitiveness: Determinants and indicators. In Current Issues in Tourism, 6(5), pp. 369-414.

[11] Vanhove, N. (2011) The Economics of Tourism Destinations. New York: Routledge, 2011. ISBN 978-0-08-096996-1.

[12] Bovaird, T. (1993) Analysing urban economic development. In Urban Studies, 30(4-5), pp. 631- 658, doi 10.1080/00420989320081851.

[13] Cheshire, P. C. - Gordon, I. R. (1998) Territorial competition: some lessons for policy. In The Annals of Regional Science, 32, pp. 321-346.

[14] Lever, W. F. (1993) Competition within the European urban system. In Urban Studies, 30, pp. 935 - 948.

[15] Meijer, M. (1993) Growth and decline of European cities: changing positions of cities in Europe. In Urban Studies, 30, pp. 981-990.

[16] Sinkienè, J. (2008) Miesto konkurencingumo veiksniai. In Viešoji politika ir administrevimas, nr. 25, pp. $67-82$.

[17] Kresl, P. - Singh, B. (2012) Urban competitiveness and US metropolitan centers. In Urban Studies, 49, pp. 239-254.

[18] McKinsey\&Company (2017) Coping with Success Managing Overcrowding in Tourism Destinations. World Travel and Tourism Council. [online]. [quoted to 20. 09. 2018].Available at: https://www.wttc.org/-/media/files/reports/policy-research/copingwith-success---managing-overcrowding-in-tourism-destinations-2017.pdf.

[19] De Albuquerque, K. - McElroy, J. L. (1992) Caribbean small-island tourism styles and sustainable strategies. In Environmental Management. 16(5), pp. 619-632.

[20] Jansen-Verbeke, M. - Spee, R. (1995) A regional analysis of tourist flows within Europe. In Tourism Management. 16(1), pp. 73-80.

[21] McElroy, J. (2003) Tourism Development in Small Islands across the World. In Geografiska Annaler. 85 B (4), pp. 231-242.

[22] Smith, M. D. - Krannich, R. S. (1998) Tourism Dependence and Resident Attitudes. In Annals of Tourism Research. Volume 25, Issue 4, 15 October, pp.783-802.

[23] Dorfman, D. (1998) Mapping Community Assets Workbook. Portland: Northwest Regional Educational Laboratory.

[24] Moore, S. (2012) Cultural Mapping: Building and Fostering Strong Communities. In D. Borwick (Ed.) Building Communities, Not Audiences: The Future of the Arts in the United States. Winston-Salem: ArtsEngaged.

[25] CzechTourism (2018) Návštěvnost turistických cílů 2017 [online]. [quoted to 20. 09. 2018]. Available at: http://www.czechtourism.cz/getattachment/Pro-media/Tiskovezpravy/Navstevnost-turistickych-cilu-v-CR-lakajihistoric/Czech_Tourism_nej_turisticke_cile.pdf.aspx?ext=.pdf.

[26] CSO (2018) Regionální časové řady. [online]. [quoted to 20. 09. 2018]. Available at: https://www.czso.cz/csu/czso/regionalni_casove_rady.

[27] MRD (2018) Statistiky a analýzy. [online]. [quoted to 01. 06. 2018]. Available at: http://www.mmr.cz/cs/Regionalni-politika-a-cestovni-ruch/Cestovni-ruch/StatistikyAnalyzy. 
[28] Prague City Tourism (2018a). Statistiky a analýzy. [online]. [quoted to 01. 06. 2018]. Available at: https://www.praguecitytourism.cz/cs/nase-cinnost/statistiky.

[29] Prague City Tourism (2018b) V roce 2017 přijelo do Prahy přes 7,5 milionu návštěvníků. [online]. [quoted to 01. 06. 2018]. Available at: https://www.praguecitytourism.cz/cs/media/tisk/v-roce-2017-prijelo-do-prahy-pres-75milionu-navstevniku-14636.

[30] KSH (2018). A lakónépesség nem szerint. [online]. [quoted to 01. 06. 2018]. Available at: http://www.ksh.hu/docs/hun/xstadat/xstadat_eves/i_wdsd003b.html

[31] TourMis (2018). Cities. [online]. [quote $\bar{d}$ to $\overline{01}$. 06. 2018]. Available at: http://www.tourmis.info/cgi-bin/tmintro.pl.

[32] Numbeo (2018) Quality of Life Comparison Between Prague and Budapest. BelgradeZvezdara: Numbeo. [online]. [quoted to 01. 06. 2018]. Available at: https://www.numbeo.com/quality-of-

life/compare_cities.jsp?country $1=$ Czech + Republic\&country $2=$ Hungary\&city $1=$ Prague \&city2=Budapest\&tracking=getDispatchComparison.

[33] Euromonitor International (2017). Top 100 City Destinations Ranking 2017. [online]. [quoted to 01. 06. 2018]. Available at: https://blog.euromonitor.com/top-100-citydestination-ranking-2017/

[34] AirDNA (2018): Budapest. Market Overview. [online]. [quoted to 12. 11. 2018]. Available at: https://www.airdna.co/vacation-rentaldata/app/hu/default/budapest/overview.

[35] Kádár, B. (2018) Hogyan használják a turisták Budapest, Bécs és Prága városi tereit? [online]. [quoted to 12. 11. 2018]. Available at: http://osszkep.hu/2016/10/hogyanhasznaljak-a-turistak-budapest-becs-es-praga-varosi-tereit/

[36] Volf, T. 2018. V soukromí bydlí víc než třetina návštěvníků Prahy, některé hotely končí. [online]. [quoted to 12. 11. 2018]. Available at: https://www.novinky.cz/ekonomika/488674-v-soukromi-bydli-vic-nez-tretinanavstevniku-prahy-nektere-hotely-konci.html. 